\title{
The Relationship Between Clinical Phenotypes and Chromosomal Microdeletions/Duplications in Pediatric Neurology
}

\author{
Pediatrik Nörolojide Klinik Fenotipler ve Kromozomal Mikrodelesyon/Duplikasyonlar \\ Arasındaki İlişki
}

\author{
Sevim TÜRAY ${ }^{1}$ \\ (i) 0000-0001-6002-052X \\ Recep ERÖZ ${ }^{2}$ \\ (D) 0000-0003-0840-2613 \\ Esra HABİLOĞLU ${ }^{2}$ \\ (D) 0000-0001-8234-3469 \\ Nadide Melike SAV ${ }^{3}$ \\ (1) 0000-0003-1520-6426
}

\begin{abstract}
Aim: The aim of this study was to determine the diagnostic utility of chromosomal microarray analysis (CMA) in daily pediatric neurology practice and to identify the guiding clinical parameters for patients requiring this test.

Material and Methods: The CMA results for 91 patients with global developmental delay/intellectual disability (GDD/ID) admitted to our pediatric neurology clinic for various reasons between 2018 and 2020 were examined. Demographical and clinical data for 34 patients $(37.4 \%)$ in whom del/dup was determined at CMA and 57 patients $(62.6 \%)$ with normal CMA were compared.

Results: There was no statistically significant difference between two groups in terms of demographic characteristics such as age, gender, type of delivery, gestational age, etc. Dysmorphisms, hypotonia, myelination abnormalities were significantly more frequent in patients with del/dup than in patients with normal result. The frequency of macrocephaly and obesity was higher in the normal group, and that of generalized seizures was higher among epileptic patients in this group. Nineteen $(55.9 \%)$ of the 34 cases who have del/dup detected at

Conclusion: Since CMA is an expensive, laborious, and time-consuming test, considering clinical parameters when requesting CMA will yield high diagnostic efficiency. A high possibility of copy number variants may be predicted in GDD/ID patients with dysmorphisms, hypotonia, and myelination delay. CMA should represent the genetic analysis of choice in pediatric neurology practice in case of no finding suggesting a different etiology in these patients. Keywords: Chromosomal microarray analysis; pediatric neurology; myelination delay; hypotonia; global developmental delay; intellectual disability.
\end{abstract}

${ }^{1}$ Düzce University Faculty of Medicine analysis were regarded as pathogenic, 15 (44.1\%) as uncertain clinical significance (likely Department of Pediatric Neurology, pathogenic, likely benign and no subclassification).

Düzce, Turkey

${ }^{2}$ Düzce University Faculty of Medicine Department of Medical Genetics, Düzce, Turkey

${ }^{3}$ Düzce University Faculty of Medicine Department of Pediatrics, Düzce, Turkey

\section{ÖZ}

Amaç: $\mathrm{Bu}$ çalışmanın amacı, günlük pediatrik nöroloji pratiğinde kromozomal mikrodizi analizinin (chromosomal microarray analysis, CMA) tanısal kullanışlılığını saptamak ve bu testi gerektiren hastalar için kılavuz olan klinik parametreler belirlemektir.

Gereç ve Yöntemler: Pediatrik nöroloji kliniğimize 2018 ve 2020 yılları arasında çeşitli nedenlerle başvuran global gelişme geriliği/zihinsel yetersizlik (global developmental delay/intellectual disability, GDD/ID) olan 91 hastanın CMA sonuçları incelendi. CMA'da del/dup tespit edilen $34(\% 37,4)$ hastanın ve normal CMA'ya sahip olan $57(\% 62,6)$ hastanın demografik ve klinik verileri karşılaştırıldı.

Bulgular: İki grup arasında yaş, cinsiyet, doğum şekli, doğum zamanı gibi demografik özellikler bakımından istatistiksel olarak anlamlı bir farklılık yoktu. Dismorfizm, hipotoni ve miyelinizasyon anormallikleri CMA'da del/dup olan hastalarda normal CMA'l1 hastalara göre önemli ölçüde daha sıktı. Normal CMA grubunda makrosefali ve obezite sıklığı daha yüksekti ve bu grupta epileptik hastalardaki generalize konvulsiyon sıklığı daha yüksekti. Analizde del/dup saptanan 34 vakadan 19'u $(\% 55,9)$ patojenik, 15'i $(\% 44,1)$ klinik önemi bilinmeyen (muhtemelen patojenik, muhtemelen iyi huylu ve sınıflandırılamayan) olarak kabul edildi.

Sonuç: CMA pahalı, zahmetli ve zaman alan bir test olduğundan, CMA talep edilirken klinik parametrelerin dikkate alınması yüksek tanısal verimlilik sağlayacaktır. Dismorfizm, hipotoni ve miyelinizasyon gecikmesi olan GDD/ID hastalarında kopya sayısı değişiklikleri yüksek

Received / Geliş Tarihi : 17.02.2021 Accepted / Kabul Tarihi : 17.04.2021 Available Online /

Çevrimiçi Yayın Tarihi : 22.04.2021

\section{Sorumlu Yazar}

Sevim TÜRAY

drsvm@yahoo.com olasılıkla saptanabilir. Bu hastalarda farklı bir etyoloji düşündüren herhangi bir bulgunun olmadığı durumlarda, CMA pediatrik nöroloji pratiğinde tercih edilebilir bir genetik analizdir. Anahtar kelimeler: Kromozomal mikrodizi analizi; pediatrik nöroloji; miyelinizasyon geriliği; hipotoni; global gelişme geriliği; zihinsel yetersizlik. 


\section{INTRODUCTION}

Global developmental delay (GDD) refers to significant retardation in two or more areas of development (gross or fine motor skills, speech and language, cognition, personal and social interactions, and activities of daily living). It affects $1-3 \%$ of children, many of whom exhibit intellectual disability (ID) subsequently $(1,2)$. The term GDD is generally used for the under-five age group, while the term ID is used at older ages due to the applicability of intelligence quotient testing (3).

Chromosomal microarray analysis (CMA) has become a routine and recommended first step test in both GDD and ID $(4,5)$. The frequency of detection of deletions or duplications in CMA increases in pediatric neurology patients with GDD/ID, hypotonia, epilepsy, and dysmorphic findings at childhood age group. In case of no additional finding leading to diagnosis, CMA can therefore be used as a screening procedure in the presence of these clinical findings. However, limited accessibility restricts the use of this test in some centers.

The purpose of present study was to identify clues capable of predicting the probability of detection of deletion and duplication in patients with this manifestation at the CMA test. We also reported data for duplications and deletions together with the cases' clinical summaries.

\section{MATERIAL AND METHODS \\ Patients}

Ninety-one patients (43 female and 48 male) aged 1-15 years who admitted to our pediatric neurology outpatient clinic for various reasons, such as dysmorphisms, microcephaly macrocephaly, epilepsy, hypotonia, motor retardation, gait disturbance, and speech retardation, and identified as requiring CMA following observation of GDD/ID between 2018 and 2020 were included in the study. Children with inborn errors of metabolism and previous causative genetic diagnoses explaining their clinical findings were excluded.

This study was approved by the local ethics committee of Düzce University $(01.06 .2020,109)$. The research made in accordance with the Declaration of Helsinki-Ethical Principles for Medical Research Involving Human Subjects. Chromosomal Microarray Analysis

Chromosomal microarray analyses have requested for all patients. Individual informed consent for medical examinations, genomic analyses, and case presentations were obtained from the parents. Genomic DNA was extracted from peripheral leukocytes of fresh blood samples collected from the patients, and chromosomal analysis was performed. DNA was isolated from peripheral blood samples, and CMA was performed using Agilent ISCA v2 Human Genome 8x60k oligonucleotide array.

\section{Study Design and Clinical Data}

CMA results of the 91 patients were evaluated retrospectively. Patients without submicroscopic deletions and/or duplications based on the CMA results were determined as Group 1, and those with submicroscopic deletions and/or duplications as Group 2.

The Denver II developmental test (6), Stanford-Binet Intelligence Scales, 5th edition (SB-5) test (7), and Wechsler Intelligence Scale for Children, 3rd edition (8), were used for the diagnosis of GDD and ID, respectively.
Age, gender, anamnesis, family history, parents' ages, and consanguinity between the parents were investigated. Anthropometric measurements, physical and neurological examinations were performed. Patients in whom micromacrocephaly, hypotonia, dysmorphisms, low weight, tall or short stature, obesity, and spasticity were identified based on the examination findings were investigated. Patients with GDD/ID, autism, attention deficit and hyperactivity disorder (ADHD), speech disability were identified. These disorders assessed also in accordance with the criteria of Diagnostic and Statistical Manual of Mental Disorders, 5th Edition (9).

All patients underwent metabolic workup (complete blood count, blood biochemistry, lactate, pyruvate, ammonia, serum amino acids, urine organic acids, free and total carnitine analysis, plasma acylcarnitine analysis, uric acid, and biotinidase activity), cranial magnetic resonance imaging (CMRI), abdominal ultrasonography, echocardiography, and ocular and hearing examinations. The CMRI results were divided into groups, and patients with corpus callosum abnormality, vascular abnormality, cortical abnormality, myelination delay, brainstem abnormality, cerebral atrophy, dilated ventricle, cavum septum pellucidum et vergae, arachnoid cyst, and normal imaging were identified.

Age at onset of seizures and seizure types (motor, nonmotor, focal or generalized seizure) were determined in epileptic patients in both groups. The epilepsy subtype classifications were based on the terminology proposed by the Commission on Classification and Terminology of the International League against Epilepsy (10). Among the patients with epilepsy, individuals with drug-resistant epilepsy and epilepsy under-control were identified based on failure of adequate trials of two tolerated, appropriately chosen, and used anticonvulsant drug schedules (whether as monotherapies or in combination) to achieve sustained seizure freedom (11). Electroencephalography (EEG) examinations were performed on all epileptic patients. EEG signals were recorded for a minimum of $30 \mathrm{~min}$ from 19 scalp electrodes, based on the International 10-20 System (Galileo NT Mizar-Sirius 33 Channels; EBNeuro) (12). Patients with focal spike, generalized spike, background abnormality, or normal findings were identified. All parameters were compared between the groups. The CMA results of the patients in Group 2 were also assessed according to the American College of Medical Genetics guidelines (13). The results were grouped in line with pathogenic, uncertain clinical significance (likely pathogenic, likely benign, no subclassification) and benign definitions. The case characteristics in this group are presented in Table A1 in the appendix.

\section{Statistical Analysis}

The data were evaluated using Statistical Package for Social Sciences (IBM Corp., Armonk, NY, USA) for Windows v.22.0 software. The descriptive statistical methods (mean, standard deviation, median, interquartile range, minimum-maximum values, number, and percentages) was used. The Kolmogorov-Simirnov and Shapiro-Wilk tests were used to examine normality assumption. Since we found that the data were not normally distributed Mann-Whitney U test was used for a 
pairwise comparison of groups. Pearson chi-square and Fisher's exact tests were applied to analyze categorical data, and odds ratios (ORs) with $95 \%$ confidence intervals (CIs) were also calculated. $\mathrm{p}$ values $<0.05$ were considered statistically significant.

\section{RESULTS}

The mean age of the patients was $5.2 \pm 3.7$ (median=4, $\min -\max =1-17)$ years. The CMA results of $57(62.6 \%)$ patients revealed no submicroscopic deletions or duplications (Group 1), while 34 (37.4\%) patients exhibited at least one of the submicroscopic deletions or duplications (Group 2).

No statistically significant difference was found between two groups in terms of age, gender, type of delivery, gestational age, birth weight, length of hospital stay during neonatal period, family history of neurological or psychiatric disease, parents' ages, or parental consanguinity (Table 1).

There was no statistically significant difference between the groups in terms of macrocephaly, microcephaly, low weight, tall stature, short stature, or spasticity parameters (Table 2).

The dysmorphology rate was significantly higher in Group 2 than in Group $1(\mathrm{p}=0.003)$. When the dysmorphology condition was considered, the risk of dysmorphology was 4.865 times higher in Group 2 than Group $1(\mathrm{OR}=4.865$, 95\% CI=1.647-14.364). A significantly higher number of obese patients was observed in Group 1 compared to Group $2(\mathrm{p}=0.023)$.

The hypotonia rate was significantly higher in Group 2 than in Group $1(\mathrm{p}=0.047)$. The risk of hypotonia was 2.682 times higher in Group 2 than in Group $1(\mathrm{OR}=2.682$, $95 \% \mathrm{CI}=1.067-6.744)$. GDD/ID ratios were similar in the two groups. No difference was also determined in proportions of patients with autism, ADHD, and speech disability (Table 2).

Table 1. Demographical characteristics of patients

\begin{tabular}{|c|c|c|c|}
\hline & $\begin{array}{c}\text { Group } 1 \\
(n=57)\end{array}$ & $\begin{array}{c}\text { Group } 2 \\
(n=34)\end{array}$ & $\mathbf{p}$ \\
\hline Age (years) & $4(5.25)[1-17]$ & $4(5.13)[1-14]$ & 0.231 \\
\hline \multicolumn{4}{|l|}{ Gender } \\
\hline Female & $26(45.6)$ & $17(50.0)$ & \multirow{2}{*}{0.685} \\
\hline Male & $31(54.4)$ & $17(50.0)$ & \\
\hline \multicolumn{4}{|l|}{ Type of delivery } \\
\hline $\mathrm{CS}$ & $36(63.2)$ & $17(50.0)$ & \multirow{2}{*}{0.218} \\
\hline NSD & $21(36.8)$ & $17(50.0)$ & \\
\hline \multicolumn{4}{|l|}{ Time of delivery } \\
\hline Preterm & $11(19.3)$ & $8(23.5)$ & \multirow{2}{*}{0.631} \\
\hline Term & $46(80.7)$ & $26(76.5)$ & \\
\hline Hospitalization & $20(35.1)$ & $9(26.5)$ & 0.393 \\
\hline SGA & $9(15.8)$ & 7 (20.6) & 0.561 \\
\hline Family history & $17(29.8)$ & $9(26.5)$ & 0.732 \\
\hline Mom age & $30(8)$ [19-41] & $26.5(6)$ [17-43] & 0.170 \\
\hline Dad age & 33 (9) [24-46] & 32 (7) [24-53] & 0.529 \\
\hline \multicolumn{4}{|l|}{ Consanguinity } \\
\hline No & $42(73.7)$ & $30(88.2)$ & \multirow{3}{*}{0.242} \\
\hline 1st degree & $9(15.8)$ & $2(5.9)$ & \\
\hline 2nd degree & $6(10.5)$ & $2(5.9)$ & \\
\hline
\end{tabular}

The distributions of patients with corpus callosum abnormality, vascular abnormality, cortical abnormality, myelination delay, brainstem abnormality, cerebral atrophy, dilated ventricle, cavum septum pellucidum et vergae, arachnoid cyst, and normal imaging were similar in two groups, as per the CMRI results (Table 2). However, the rate of myelin abnormalities was significantly higher in Group 2 than in Group 1 ( $\mathrm{p}=0.014)$. The risk of myelin abnormalities was 4.77 times higher in Group 2 than in Group $1(\mathrm{OR}=4.770,95 \% \mathrm{CI}=1.339-16.988)$.

The frequency of epilepsy was similar between the groups $(p=0.304)$. Nineteen of the 34 patients with epilepsy were from Group 1 and 15 were from Group 2. When epileptic patients were compared, no statistically significant difference was found between the groups in terms of age at onset of seizures, response to antiepileptic drugs, and EEG abnormalities (Table 3). In terms of seizure types, the frequency of generalized seizures in Group 1 was higher than in Group $2(\mathrm{p}=0.011)$.

Table 2. Comparison of patients with and without submicroscopic deletions and/or duplications, n (\%)

\begin{tabular}{|c|c|c|c|}
\hline & $\begin{array}{c}\text { Group } 1 \\
(n=57)\end{array}$ & $\begin{array}{c}\text { Group } 2 \\
(n=34)\end{array}$ & $\mathbf{p}$ \\
\hline Short Stature & $15(26.3)$ & $15(44.1)$ & 0.081 \\
\hline Tall Stature & $1(1.8)$ & $2(5.9)$ & 0.553 \\
\hline Macrocephaly & $9(15.8)$ & $1(2.9)$ & 0.084 \\
\hline Microcephaly & $22(38.6)$ & $8(23.5)$ & 0.139 \\
\hline Dysmorphology & $31(54.4)$ & $29(85.3)$ & 0.003 \\
\hline Nonambulatuar & $19(33.3)$ & $9(26.5)$ & 0.493 \\
\hline Spasticity & $2(3.5)$ & $1(2.9)$ & 0.999 \\
\hline Obesity & $8(14.0)$ & $0(0.0)$ & 0.023 \\
\hline Hypotonia & $29(50.9)$ & $25(73.5)$ & 0.047 \\
\hline GDD/ID & $50(87.7)$ & $32(94.1)$ & 0.475 \\
\hline GR & $15(26.3)$ & $15(44.1)$ & 0.081 \\
\hline Speech disability & $41(71.9)$ & $29(85.3)$ & 0.143 \\
\hline CC abnormality & $10(17.5)$ & $8(23.5)$ & 0.488 \\
\hline Vascular abnormality & $1(1.8)$ & $1(2.9)$ & 0.999 \\
\hline Cortical abnormality & $2(3.5)$ & $0(0.0)$ & 0.527 \\
\hline Cardiac abnormality & $5(8.8)$ & $5(14.7)$ & 0.492 \\
\hline Renal abnormality & $2(3.5)$ & $1(2.9)$ & 0.999 \\
\hline Vision abnormality & $10(17.5)$ & $2(5.9)$ & 0.199 \\
\hline Hearing abnormality & $4(7.0)$ & $2(5.9)$ & 0.999 \\
\hline Myelin abnormality & $4(7.0)$ & $9(26.5)$ & 0.014 \\
\hline Cavum septum & $3(5.3)$ & $3(8.8)$ & 0.668 \\
\hline Arachnoid cyst & $9(15.8)$ & $4(11.8)$ & 0.760 \\
\hline Brainstem abnormality & $6(10.5)$ & $3(8.8)$ & 0.999 \\
\hline Cerebral atrophy & $6(10.5)$ & $5(14.7)$ & 0.741 \\
\hline Dilated ventricle & $7(12.3)$ & $3(8.8)$ & 0.738 \\
\hline HSM & $3(5.3)$ & $3(8.8)$ & 0.668 \\
\hline PVL & $0(0.0)$ & $2(5.9)$ & 0.137 \\
\hline Normal CMRI & $32(56.1)$ & $18(52.9)$ & 0.767 \\
\hline Epilepsy & $19(33.3)$ & $15(44.1)$ & 0.304 \\
\hline
\end{tabular}

GDD/ID: global developmental delay/intellectual disability, GR: growth retardation, CC: corpus callosum, HSM: hepatosplenomegaly, PVL: periventricular leukomalacia, CMRI: cranial magnetic resonance imaging 
Table 3. Comparison of epileptic patients with and without submicroscopic deletions and/or duplications $(n=34)$

\begin{tabular}{lccc}
\hline & $\begin{array}{c}\text { Group 1 } \\
(\mathbf{n = 1 9 )}\end{array}$ & $\begin{array}{c}\text { Group 2 } \\
(\mathbf{n = 1 5})\end{array}$ & $\mathbf{p}$ \\
\hline Age at seizure onset & $1.5(2.5)[0-9.5]$ & $1.75(2)[0-11]$ & 0.557 \\
Focal spike & $9(47.4)$ & $8(53.3)$ & 0.730 \\
Generalized Spike & $8(42.1)$ & $3(20.0)$ & 0.271 \\
Normal EEG & $3(15.8)$ & $4(26.7)$ & 0.672 \\
Background abnormality & $8(42.1)$ & $6(40.0)$ & 0.901 \\
Controlled epilepsy & $11(57.9)$ & $9(60.0)$ & 0.901 \\
Resistant epilepsy & $8(42.1)$ & $6(40.0)$ & 0.901 \\
Motor seizure & $16(84.2)$ & $13(86.7)$ & 0.999 \\
Non-motor seizure & $7(36.8)$ & $3(20.0)$ & 0.451 \\
Focal seizure & $3(15.8)$ & $4(26.7)$ & 0.672 \\
Generalize seizure & $19(100)$ & $10(66.7)$ & $\mathbf{0 . 0 1 1}$
\end{tabular}

EEG: Electroencephalography, descriptive statistics were presented as n (\%) for categorical variables, and as median (interquartile range) [minimum-maximum] for numerical variables

\section{Clinical Characteristics and CMA Results of Patients with Submicroscopic Deletions and/or Duplications}

Nineteen patients' mutations detected were considered pathogenic (55.9\% of the Group 2, 20.9\% of the total), fifteen patients' mutations were designated as uncertain clinical significance $(44.1 \%$ of the Group $2,16.5 \%$ of the total). These were separated as likely pathogenic, likely benign and no subclassification among themselves. The clinical features of these patients and their CMA results are shown in Table A1 in the appendix.

\section{DISCUSSION}

No etiology can be determined in some pediatric neurology patients. Although the possibility of diagnosing some patients has been increased by novel genetic technologies introduced in recent years, the use of these tests $\mathrm{s}$ restricted by cost and transportation problems. CMA was performed on patients with GDD/ID and admitted to the pediatric neurology outpatient clinic of our hospital for various reasons. Statistically significant findings emerged in some clinical data when patients with duplication/deletion were compared with those with normal CMA results.

Numerous studies in recent years have shown the sensitivity of CMA analysis in patients with GDD/ID, autistic spectrum disorder (ASD), and dysmorphic findings, and have recommended its use as a first-line screening test $(4,5)$. CMA is 100 times more sensitive than karyotype analysis and makes a $15-20 \%$ contribution to diagnosis (4). In a recent study, the diagnostic efficiency of CMA was found $31.7 \%$ on the patients who have GDD/ID (14). Shoukier et al. (15), observed more microcephaly, short stature, failure to thrive, and especially congenital heart defects, in patients with pathology detected as a result of CMA analysis compared to patients with normal results in a series of 342 cases with GDD/ID. Even though no statistically significant difference was observed between two groups in terms of microcephaly and macrocephaly in the present study, the rate of macrocephaly was higher markedly in Group 1. In terms of the genetic causes of macrocephaly, the etiology includes neurocutaneous and neurometabolic diseases, which are generally caused by single-gene disorders, and syndromes with overgrowth caused by a single gene disorder (16). In other words, macrocephaly is frequently seen with chromosomal del/dup.

Studies have reported a high frequency of congenital anomalies in patients with pathogenic copy number variants (CNVs) (17,18). In one recent piece of research, patients who underwent CMA were divided into four groups as isolated ID/DD, DD/ID with multiple congenital anomalies (MCA), isolated ASD, and DD/ID with epilepsy. CNV rates were significantly higher in the DD/ID with MCA group than in the other three groups (19). Consistent with the previous literature, the rate of dysmorphisms was significantly higher in Group 2 compared to Group 1 in the present study.

Failure to thrive may frequently accompany chromosomal diseases. Shoukier et al. (15), observed higher birth weight and subsequent failure to thrive in patients with pathology at CMA compared to patients with normal CMA. The role of CNVs was also emphasized in a study conducted with newborns to determine the etiology of small for gestational age (20). Although failure to thrive is commonly observed with pathological CNVs, new submicroscopic deletions and duplications are also implicated at the etiology of obesity $(21,22)$. In the present study, although there was no difference between the two groups in terms of low weight, tall stature, short stature, or birth weight, the obesity rate was higher in Group 1. While no statistically significant difference was determined, low weight and short stature rates in Group 2 were higher than in Group 1. This result may suggest that del/dups detected for pediatric neurology patients with GDD/ID mostly create a failure to thrive.

Despite the fact that structural chromosomal abnormality is among the known etiological factors in hypotonia, this can also be caused by several neurological diseases (23). The hypotonia rate in Group 2 was statistically significantly higher than in Group 1. In other words, it may be concluded that hypotonia increases the risk of deletion/duplication detection 2.68-fold at CMA.

The importance of rare CNVs in generalized or focal childhood epilepsy is well known (24). CNVs have also been associated with epileptic encephalopathy (25), atypical rolandic epilepsy (26), epilepsy with intellectual disability (27), absence epilepsy (28) and fever-related syndromes (29) in previous studies. We observed no significant difference in epilepsy rates between our patient groups with and without CNV. Seizure patterns were generalized in all patients in Group 1, while Group 2 contained patients with focal seizures. This difference was statistically significant. We attribute this result to the study being record-based. Although no previous research has shown a relationship between seizure types and CNV, studies have investigated the association between focal and generalized epilepsy types and CNV. Perez et al. (30), reported 1.139-fold greater risk of microdeletion development in patients with epilepsy than in a control group (micro del carrier rates were $4.85 \%$ in the epilepsy group and $3.47 \%$ in the control group). They also determined that microdeletions had an essential role in the genetic structure in the genetic generalized epilepsy group, and made a minor contribution in rolandic epilepsy and adult focal epilepsy. 
Coppola et al. (31), recent study emphasized the importance of CNVs in patients defined as epilepsy plus (epilepsy and comorbid features), and reported new pathogenic CNV and candidate genes. They also reported approximate $\mathrm{CNV}$ rates of $12 \%$ in patients with comorbidities with epilepsy of unknown cause and recommended that these be investigated.

The importance of CNVs in this group was emphasized in another study with a reported diagnostic yield of approximately $15 \%$ in a group of 92 patients with epilepsy and ID (32). In the present study, $15(44.1 \%)$ of the 34 patients in Group 2 had epilepsy. This shows that CNVs are commonly encountered in epilepsy patients with ID/GDD and whose etiology has not been determined, and are necessary for diagnosis.

Cranial magnetic resonance imaging is performed as part of the evaluation of patients with GDD/ID in the presence of additional neurological findings (abnormal head circumference, focal neurological signs, or epilepsy). Detection of CMRI abnormalities in patients with specific genetic syndromes, inborn errors of metabolism, or perinatal acquired injury helps to establish the diagnosis (33). Heide et al. (34), found CNV in $13 \%$ of patients with both corpus callosum abnormality and intellectual disability and thought that this might explain the possible cause of the disease. In another study, CNV was detected in $14 \%$ of 108 patients with corpus callosum anomalies who underwent CMA, and was found to be responsible for the pathogenesis in half of these cases (35). In a study investigating the relationship between cerebellar anomalies and $\mathrm{CNV}$, the authors determined that cerebellar lesions will not be supported by the presence of CNV other than patients with Dandy-Walker malformation or complex poly-malformative phenotypes (36). In the present study, comparison of the CMRI findings of patients with corpus callosum abnormality, vascular abnormality, cortical abnormality, brainstem abnormality, cortical atrophy, dilated ventricle, periventricular leukomalacia, cavum septum pellucidum et vergae, arachnoid cyst, normal imaging parameters, revealed no differences between the two groups. However, rates of white matter disorders such as periventricular myelin changes, myelination delay, and non-specific myelin defects were higher in patients with del/dup in $\mathrm{CNV}$ than in those with normal CNV. Determination of deletion or duplication in patients with $\mathrm{CNV}$ increased the risk of myelination disorders 4.77 -fold compared to the normal group.

Vigdorovich et al. (37), also determined that different chromosomal micro-rearrangement syndromes create nonspecific multifocal and especially periventricular white matter changes as a common feature at CMRI. The authors also reported that these lesions may also be accompanied by corpus callosum dysgenesis or gray matter loss. These findings support our own study.

We detected pathological deletion/duplication in 20 $(22.0 \%)$ of the 91 patients in this study. This rate was higher than average in terms of diagnostic yield, according to the previous literature. This may be due to CMA, the third step, being necessarily performed in patients with GDD/ID who present to our hospital with various neurological problems after other etiological investigations have been performed. A diagnostic yield of
$10.2 \%(0-50 \%)$ was reported in a report of 18 studies of patients with GDD/ID with facial dysmorphism, congenital anomalies, or neurological symptoms (38). We detected CNV in 34 patients $(37.4 \%$ ) (pathogenic and unknown clinical significance). D'Arrigo et al. (39), found pathological significance in $16 \%$ and unknown clinical significance in $31 \%$ of 329 cases.

The most important limitation of our study is its retrospective nature. Also, the number of our patients was small. We also realize that our classification is imperfect, and we were only able to perform parental CMA in a small number of cases.

\section{CONCLUSIONS}

This study demonstrates the importance of the use of CMA in the first step in patients with dysmorphisms, hypotonia, or myelination disorders with GDD/ID. We also think that CNVs will be more common in pediatric neurology patients with microcephaly and failure to thrive. The role of CMA in the diagnosis of epileptic patients with undetermined etiology and GDD/ID association should not be ignored. The increasing identification of new CNVs and the growing identification of pathogenic CNVs will finally determine the place of CMA analysis in pediatric neurology patients.

Ethics Committee Approval: The study was approved by the Ethics Committee of Düzce University Faculty of Medicine (01.06.2020, 109).

Conflict of Interest: None declared by the authors.

Financial Disclosure: None declared by the authors.

Acknowledgements: None declared by the authors.

Author Contributions: Idea/Concept: ST, RE; Design: ST, RE; Data Collection/Processing: ST, RE, EH, NMS; Analysis/Interpretation: ST, RE; Literature Review: ST, RE, EH, NMS; Drafting/Writing: ST, RE, EH, NMS; Critical Review: ST, RE, EH, NMS.

\section{REFERENCES}

1. Yeargin-Allsopp M, Murphy CC, Cordero JF, Decouflé P, Hollowell JG. Reported biomedical causes and associated medical conditions for mental retardation among 10-year-old children, metropolitan Atlanta, 1985 to 1987 . Dev Med Child Neurol. 1997;39(3):142-9.

2. Petersen MC, Kube, DA, Palmer FB. Classification of developmental delays. Semin Pediatr Neurol. 1998;5(1):2-14.

3. Shevell M. Global developmental delay and mental retardation or intellectual disability: conceptualization, evaluation, and etiology. Pediatr Clin North. 2008;55(5):1071-84.

4. Miller DT, Adam MP, Aradhya S, Biesecker LG, Brothman AR, Carter NP, et al. Consensus statement: chromosomal microarray is a first- tier clinical diagnostic test for individuals with developmental disabilities or congenital anomalies. Am J Hum Genet. 2010;86(5): 749-64. 
5. Battaglia A, Doccini V, Bernardini L, Novelli A, Loddo S, Capalbo A, et al. Confirmation of chromosomal microarray as a first-tier clinical diagnostic test for individuals with developmental delay, intellectual disability, autism spectrum disorders and dysmorphic features. Eur J Paediatr Neurol. 2013;17(6):589-99.

6. Yalaz K, Epir S. The Denver Developmental Screening Test: normative data for Ankara children. Turk J Pediatr. 1983;25(4):245-58.

7. Roid GH. Stanford-Binet intelligence scales, 5th ed. Itasca, IL: Riverside Publishing; 2003.

8. Wechsler D. Wechsler Intelligence Scale for Children, 3rd ed. San Antonio, TX: The Psychological Corporation; 2006.

9. American Psychiatric Association. Diagnostic and Statistical Manual of Mental Disorders, 5th ed. Washington, DC: American Psychiatric Association; 2013.

10. Berg AT, Berkovic SF, Brodie MJ, Buchhalter J, Cross $\mathrm{JH}$, van Emde Boas W, et al. Revised terminology and concepts for organization of seizures and epilepsies: report of the ILAE Commission on Classification and Terminology, 2005-2009. Epilepsia. 2010;51(4):676-85.

11. Kwan P, Arzimanoglou A, Berg AT, Brodie MJ, Allen Hauser W, Mathern G, et al. Definition of drug resistant epilepsy: consensus proposal by the ad hoc Task Force of the ILAE Commission on Therapeutic Strategies. Epilepsia. 2010;51(6):1069-77.

12. Jasper HH. The ten-twenty electrode system of the international federation. Electroencephalogr Clin Neurophysiol. 1958;10:371-75.

13. Kearney HM, Thorland EC, Brown KK, QuinteroRivera F, South ST, Working Group of the American College of Medical Genetics Laboratory Quality Assurance Committee. American College of Medical Genetics standards and guidelines for interpretation and reporting of postnatal constitutional copy number variants. Genet Med. 2011;13(7):680-85.

14. Gürkan H, Atli EI, Atli E, Bozatli L, Altay MA, Yalçıntepe S, et al. Chromosomal microarray analysis in Turkish patients with unexplained developmental delay and intellectual developmental disorders. Noro Psikiyatr Ars. 2020;57(3):177-91.

15. Shoukier M, Klein N, Auber B, Wickert J, Schröder J, Zoll B, et al. Array $\mathrm{CGH}$ in patients with developmental delay or intellectual disability: are there phenotypic clues to pathogenic copy number variants? Clin Genet. 2013;83(1):53-65.

16. Tan AP, Mankad K, Gonçalves FG, Talenti G, Alexia E. Macrocephaly: Solving the diagnostic dilemma. Top Magn Reson Imaging. 2018;27(4):197-217.

17. Lu XY, Phung MT, Shaw CA, Pham K, Neil SE, Patel A, et al. Genomic imbalances in neonates with birth defects: high detection rates by using chromosomal microarray analysis. Pediatrics. 2008;122(6):1310-8.

18. Cooper GM, Coe BP, Girirajan S, Rosenfeld JA, Vu $\mathrm{TH}$, Baker C, et al. A copy number variation morbidity map of developmental delay. Nat Genet. 2011;43(9):838-46.

19. Hu T, Zhang Z, Wang J, Li Q, Zhu H, Lai Y, et al. Chromosomal aberrations in pediatric patients with developmental delay/intellectual disability: A single- center clinical investigation. Biomed Res Int. 2019;2019:9352581.

20. Stalman SE, Solanky N, Ishida M, Alemán-Charlet C, Abu-Amero S, Alders M, et al. Genetic analyses in small-for-gestational-age newborns. J Clin Endocrinol Metab. 2018;103(3):917-25.

21. Micleaa D, Al-Khzouza C, Osan S, Bucerzan S, Cret V, Popp RA, et al. Genomic study via chromosomal microarray analysis in a group of Romanian patients with obesity and developmental disability/intellectual disability. J Pediatr Endocrinol Metab. 2019;32(7):667-74.

22. Vuillaume ML, Naudion S, Banneau G, Diene G, Cartault A, Cailley D, et al. New candidate loci identified by array-CGH in a cohort of 100 children presenting with syndromic obesity. Am J Med Genet A. $2014 ; 164 \mathrm{~A}(8): 1965-75$.

23. Harris SR. Congenital hypotonia: clinical and developmental assessment. Dev Med Child Neurol. 2008;50(12):889-92.

24. Olson H, Shen Y, Avallone J, Sheidley BR, Pinsky R, Bergin AM, et al. Copy number variation plays an important role in clinical epilepsy. Ann Neurol. 2014;75(6):943-58.

25. Mefford HC, Yendle SC, Hsu C, Cook J, Geraghty E, McMahon JM, et al. Rare copy number variants are an important cause of epileptic encephalopathies. Ann Neurol. 2011;70(6):974-85.

26. Reinthaler EM, Lal D, Lebon S, Hildebrand MS, Dahl HH, Regan BM, et al. 16p11.2 600 kb Duplications confer risk for typical and atypical Rolandic epilepsy. Hum Mol Genet. 2014;23(22):6069-80.

27. Mullen SA, Carvill GL, Bellows S, Bayly MA, Trucks $\mathrm{H}$, Lal D, et al. Copy number variants are frequent in genetic generalized epilepsy with intellectual disability. Neurology. 2013;81(17):1507-14.

28. Addis L, Rosch RE, Valentin A, Makoff A, Robinson $\mathrm{R}$, Everett KV, et al. Analysis of rare copy number variation in absence epilepsies. Neurol Genet. 2016;2(2):e56.

29. Hartmann C, von Spiczak S, Suls A, Weckhuysen S, Buyse $\mathrm{G}$, Vilain $\mathrm{C}$, et al. Investigating the genetic basis of fever-associated syndromic epilepsies using copy number variation analysis. Epilepsia. 2015;56(3):e2632.

30. Pérez-Palma E, Helbig I, Klein KM, Anttila V, Horn $\mathrm{H}$, Reinthaler EM, et al. Heterogeneous contribution of microdeletions in the development of common generalised and focal epilepsies. J Med Genet. 2017;54(9):598-606.

31. Coppola A, Cellini E, Stamberger H, Saarentaus E, Cetica V, Lal D, et al. Diagnostic implications of genetic copy number variation in epilepsy plus. Epilepsia. 2019;60(4):689-706.

32. Peycheva V, Kamenarova K, Ivanova N, Stamatov D, Avdjieva-Tzavella D, Alexandrova I, et al. Chromosomal microarray analysis of Bulgarian patients with epilepsy and intellectual disability. Gene. 2018;667:45-55.

33. Mithyantha R, Kneen R, McCann E, Gladstone M. Current evidence-based recommendations on investigating children with global developmental delay. Arch Dis Child. 2017;102(11):1071-6. 
34. Heide S, Keren B, Billette de Villemeur T, ChantotBastaraud S, Depienne C, Nava C, et al. Copy number variations found in patients with a corpus callosum abnormality and intellectual disability. J Pediatr. 2017;185:160-6.e1.

35. Romaniello R, Marelli S, Giorda R, Bedeschi MF, Bonaglia MC, Arrigoni F, et al. Clinical characterization, genetics, and long-term follow-up of a large cohort of patients with agenesis of the corpus callosum. J Child Neurol. 2017;32(1):60-71.

36. Ciaccio C, Pantaleoni C, Bulgheroni S, Sciacca F, D'Arrigo S. Chromosomal microarray analysis has a poor diagnostic yield in children with developmental delay/intellectual disability when concurrent cerebellar anomalies are present. Cerebellum. 2020;19(5):62935.
37. Vigdorovich N, Ben-Sira L, Blumkin L, Precel R, Nezer I, Yosovich K, et al. Brain white matter abnormalities associated with copy number variants. Am J Med Genet A. 2020;182(1):93-103.

38. Michelson DJ, Shevell MI, Sherr EH, Moeschler JB, Gropman AL, Ashwal S. Evidence report: Genetic and metabolic testing on children with global developmental delay: report of the Quality Standards Subcommittee of the American Academy of Neurology and the Practice Committee of the Child Neurology Society. Neurology. 2011;77(17):1629-35.

39. D'Arrigo S, Gavazzi F, Alfei E, Zuffardi O, Montomoli C, Corso B, et al. The diagnostic yield of array comparative genomic hybridization is high regardless of severity of intellectual disability/developmental delay in children. J Child Neurol. 2016;31(6):691-9. 
The Appendix:

Table A1. Clinical and genetic features of patients whose chromosomal microarray analysis results were evaluated

\begin{tabular}{|c|c|c|c|c|c|c|c|}
\hline No & Sex/Age & Clinical Manifestations & Neuroimaging & $\begin{array}{l}\text { CMA results/ } \\
\text { Significance }\end{array}$ & Size & Start & Responsible genes \\
\hline 1 & $\mathrm{M} / 7.5$ & $\begin{array}{l}\text { Drug-resistant epilepsy (myoclonic- } \\
\text { astatic seizures), Macrodactyly and } \\
\text { syndactyly on the 2nd and 3rd toes of } \\
\text { the left food ID, ATX gene normal }\end{array}$ & Normal & $\begin{array}{l}2 \mathrm{q} 13 \\
\text { UCS;NS } \\
6 \mathrm{p} 21.32 \\
\text { UCS;LP }\end{array}$ & $\begin{array}{l}0.3 \mathrm{MB} \\
\mathrm{dup} \\
0.2 \mathrm{MB} \text { del }\end{array}$ & $\begin{array}{l}(110783236-111103309) \times 3 \\
\text { İnherited, } \\
(32688930-32956557) \times 1 \\
\text { De novo }\end{array}$ & $\begin{array}{l}\text { 2q13: } M A L L, N P H P \\
\text { 6p21.32: } H L A-D Q A 2, H L A-D Q B 2, H L A- \\
D O B, T A P 2, P S M B 8, T A P 1, P S M B 9, H L A- \\
D M B, H L A-D M A, B R D\end{array}$ \\
\hline 2 & $\mathrm{M} / 2.5$ & $\begin{array}{l}\text { Hypotonia, GDD, Atypical autism, } \\
\text { SD, Left ear SNHL }\end{array}$ & Normal & $\begin{array}{l}\text { 15q13.2q13.3 } \\
\text { Pathogenic }\end{array}$ & $1.5 \mathrm{MB}$ del & $\begin{array}{l}(30654726-32509926) \times 1 \\
\text { unknown }\end{array}$ & $\begin{array}{l}\text { ARHGAP11B,CHRFAM7A,CHRNA7,FAN1,K } \\
\text { LF13,OTUD7A,TRPM1 }\end{array}$ \\
\hline 3 & $\mathrm{M} / 7.5$ & $\begin{array}{l}\text { GDD, Diplegia, Spasticity } \\
\text { Autism, SD, Epilepsy (generalized } \\
\text { motor seizures), FD, Microcephaly, } \\
\text { GR, SGA, Epilepsy }\end{array}$ & $\begin{array}{l}\text { Cerebral atrophy } \\
\text { Thin CC }\end{array}$ & $\begin{array}{l}\text { 12q13.12q13.13 } \\
\text { UCS;LP } \\
13 q 13.1 \\
\text { UCS;NS }\end{array}$ & $\begin{array}{l}2.4 \mathrm{MB} \\
\mathrm{del} \\
0.4 \mathrm{MB} \text { del }\end{array}$ & $\begin{array}{l}(50157351-52618686) \times 1, \\
(32533833-32937352) X 1 \\
\text { De novo }\end{array}$ & $\begin{array}{l}\text { 12q13.12q13.13:TBMIM6,NCKAPL5,FAIM2, } \\
\text { AQP2,AQP5, SMARCD1, GPD1, COXI4 } \\
\text { 13q13.1:CERS5,LIMA1,DIP } 2 B, A T F 1, T F C P 2 \\
\text {, BIN2,CELA1,GALNT6,SLC4A8,ACVRL1, } \\
\text { ACVR1B,GRASP, NR4A1, ATG101, KRT8O }\end{array}$ \\
\hline 4 & $\mathrm{~F} / 2$ & $\begin{array}{l}\text { Rubinstein-Taybi, Drug-resistant } \\
\text { epilepsy (focal motor seizures), GDD, } \\
\text { FD, Microcephaly, GR, SGA, SD, } \\
\text { Right eye cataract, PS/ASD }\end{array}$ & $\begin{array}{l}\text { Thin CC, myelination } \\
\text { delay }\end{array}$ & \begin{tabular}{|l|} 
16p13.3 \\
Pathogenic
\end{tabular} & $\begin{array}{l}52 \mathrm{~KB} \\
\mathrm{del}\end{array}$ & $\begin{array}{l}(378,3001-383,5116) \times 1 \\
\text { unknown }\end{array}$ & CREBBP \\
\hline 5 & $\mathrm{~F} / 3.5$ & $\begin{array}{l}\text { GDD, SD, FD, Microcephaly, } \\
\text { Epilepsy (non-motor seizures), } \\
\text { Simian sign, Broad thumbs and first } \\
\text { toes }\end{array}$ & $\begin{array}{l}\text { Thin CC, myelination } \\
\text { delay }\end{array}$ & $\begin{array}{l}15 \mathrm{q} 11.2 \\
\text { Pathogenic }\end{array}$ & $0.5 \mathrm{MB}$ del & $\begin{array}{l}(227,656,28-233,00,287) \times 1 \\
\text { unknown }\end{array}$ & TUBGCP5,CYFIP1,NIPA2,NIPA1 \\
\hline 6 & $\mathrm{M} / 3$ & $\begin{array}{l}\text { GDD, FD } \\
\text { Epicanthus, Upslanted palpebral } \\
\text { fissure, Micrognathia, SS, Epilepsy } \\
\text { (hot water epilepsy), SGA, Unsteady } \\
\text { gait, Foot and toe deformity, } \\
\text { Brainstem hypoplasia }\end{array}$ & $\begin{array}{l}\text { Cerebral and } \\
\text { cerebellar atrophy, } \\
\text { increased } \\
\text { subarachnoid space, } \\
\text { cystic dilated fourth } \\
\text { ventricle, hypoplasia } \\
\text { of brainstem } \\
\end{array}$ & $\begin{array}{l}\text { Xp22.33 } \\
\text { UCS;LP } \\
\text { Yp11.32 } \\
\text { UCS:LB }\end{array}$ & $\begin{array}{l}0.1 \mathrm{MB} \\
\operatorname{dup}\end{array}$ & $\begin{array}{l}\text { 602488-733497)x3 } \\
\text { Maternal inherited } \\
552488-683497) \times 3 \\
\text { Denovo }\end{array}$ & $\begin{array}{l}\text { SHOX } \\
\text { No gene }\end{array}$ \\
\hline 7 & $\mathrm{M} / 1.5$ & $\begin{array}{l}\text { GDD, GR and Short stature, } \\
\text { Microcephaly, Recurrence infection, } \\
\text { Di George syndrome } \\
\text { Telangiectasia in the ear, } \\
\text { ATX gene normal, } \\
\text { CFTR gene normal }\end{array}$ & Normal & $\begin{array}{l}22 \mathrm{q} 11.21 \\
\text { Pathogenic }\end{array}$ & $2.8 \mathrm{MB}$ del & $\begin{array}{l}(18628019-21440514) \times 1 \\
\text { unknown }\end{array}$ & $\begin{array}{l}\text { USP18, DGCR6, PRODH, DGCR2, TSSK2, } \\
\text { GSC2, SLC25A1, CLTCL1, HIRA, MRPL40, } \\
\text { UFD1L, CLDN5, SEPT5, GP1BB,TBX1, } \\
\text { GNB1L, TXNRD2, COMT, ARVCF, } \\
\text { TANGO2, MIR185, DGCR8, TRMT2A, } \\
\text { RANBP1, ZDHHC8, RTN42, DGCRGL, } \\
\text { RIMBP3, ZNF74, SCARF2, MED15, PI4KA, } \\
\text { SERPIND1, SNAP29, CRKL, LZTR1, SLC7A4 } \\
\end{array}$ \\
\hline 8 & $\mathrm{~F} / 5.5$ & $\begin{array}{l}\text { SD, FD, High palate, low set ears, } \\
\text { triangular facial shape, Hypertelorism, } \\
\text { ID, SGA }\end{array}$ & $\begin{array}{l}\text { Periventricular } \\
\text { myelination } \\
\text { abnormality }\end{array}$ & $\begin{array}{l}\text { 19p12q11 } \\
\text { UCS;LP }\end{array}$ & $3.7 \mathrm{MB}$ del & $\begin{array}{l}(24378197-28095812) x 1 \\
\text { unknown }\end{array}$ & no known gene in this region \\
\hline 9 & $\mathrm{~F} / 4.5$ & $\begin{array}{l}\text { GDD, GR, Microcephaly } \\
\text { FD, Coarse facial features }\end{array}$ & Normal & $\begin{array}{l}\text { 4p16.1 } \\
\text { UCS;NS }\end{array}$ & $\begin{array}{l}0.7 \mathrm{MB} \\
\text { dup }\end{array}$ & $\begin{array}{l}(9766686-10520199) \times 4 \\
\text { Unknown }\end{array}$ & DRD5, SLC2A9, WDR1, CLNK \\
\hline
\end{tabular}




\begin{tabular}{|c|c|c|c|c|c|c|c|}
\hline 10 & $\mathrm{~F} / 7$ & $\begin{array}{l}\text { GDD, FD, Teeth abnormality, Low } \\
\text { set ears, low posterior hairline, Coarse } \\
\text { face, hypertelorism, prominent beak } \\
\text { nose, SD, Cleft lip and palate, } \\
\text { Epilepsy(non-motor and generalized } \\
\text { motor seizures), ID, Foot deformity, } \\
\text { Scoliosis, scapula alata, Clinodactyly, } \\
\text { retrognathia }\end{array}$ & $\begin{array}{l}\text { Partial agenesis of } \\
\text { CC, cavum septum } \\
\text { pellucidum et vergae, } \\
\text { colpocephaly, } \\
\text { increased } \\
\text { subarachnoid space } \\
\end{array}$ & $\begin{array}{l}\text { 6q26 } \\
\text { UCS;NS }\end{array}$ & $\begin{array}{l}0.4 \mathrm{MB} \\
\text { dup }\end{array}$ & $\begin{array}{l}\text { 162619277-163055489)x3 } \\
\text { Unknown }\end{array}$ & PARK2 \\
\hline 11 & $\mathrm{~F} / 2.5$ & $\begin{array}{l}\text { Phelan McDermid syndrome, } \\
\text { Anithelix Prominent intertriginous } \\
\text { folds, Clinodactyly Unsteady gait, } \\
\text { SD, GDD }\end{array}$ & Normal & $\begin{array}{l}\text { 22q13.31q13.33 } \\
\text { Pathogenic }\end{array}$ & $3.1 \mathrm{MB}$ del & $\begin{array}{l}(47987698-51169045) \times 1 \\
\text { unknown }\end{array}$ & $\begin{array}{l}\text { ADM2, ALG12, ARS, BRD1, CHKB, CPT1B, } \\
\text { CRELD2, FAM19A5, HDAC10, IL17REL, } \\
\text { MAPK11, MAPK12, MAPK8IP2, MIOX, } \\
\text { MLC1, MOV1OL1, NCAPH2, PANX2, PIM3, } \\
\text { PLXNB2, PPP6R2, SBF1, SCO2, SHANK3, } \\
\text { SYCE3, TUBGCP6, TYMP, ZBED4 }\end{array}$ \\
\hline 12 & $\mathrm{~F} / 13$ & $\begin{array}{l}\text { SS, Overweight, Hypochondroplasia, } \\
\text { Coarse face, Steady gait, ID }\end{array}$ & Normal & $\begin{array}{l}\text { 19p12 } \\
\text { UCS:LB }\end{array}$ & $\begin{array}{l}0.7 \mathrm{MB} \\
\text { del }\end{array}$ & $\begin{array}{l}(20216230-21001208) \times 1 \\
\text { Paternal inherited }\end{array}$ & ZNF90,ZNF737 \\
\hline 13 & $\mathrm{~F} / 1$ & $\begin{array}{l}\text { Strabismus, Optic nerve pathology, } \\
\text { FD, Ptosis of the right eye, Long } \\
\text { eyelashes, Low-set ears, Mongoloid } \\
\text { eyes, Sacral dimple, GR, GDD }\end{array}$ & Normal & $\begin{array}{l}4 \mathrm{q} 28.2 \mathrm{q} 28.3 \\
4 \mathrm{q} 28.3 \mathrm{q} 31.21 \\
4 \mathrm{q} 32.1 \\
4 \mathrm{q} 34.3 \\
\text { Pathogenic }\end{array}$ & $\begin{array}{l}3 \mathrm{MB} \\
9 \mathrm{MB}, \\
1.8 \mathrm{MB} \\
2.6 \mathrm{MB} \text { del }\end{array}$ & $\begin{array}{l}129223349-132575313) \times 1 \\
(134924076-144240473) \times 1 \\
(158444071-160299086) \times 1 \\
(177605696-180305067) \times 1 \\
\text { Unbalanced segregation } \\
\text { of a balanced translocation }\end{array}$ & $\begin{array}{l}\text { JADE1,SCLT1/CCRN4L,CLGN,ELMOD2,IL1 } \\
\text { 5,INPP4B,MAML3,MGST2,NAA15,PCDH18, } \\
\text { RAB33B,SETD7,SLC7A11,TBC1D9,UCP1,U } \\
\text { SP38,ZNF330/C4orf46,ETFDH,PPID,RAPG } \\
\text { EF2,RXFP1/AGA,NEIL3,VEGFC }\end{array}$ \\
\hline 14 & $\mathrm{M} / 11.5$ & $\begin{array}{l}\text { Epilepsy (generalized motor seizures), } \\
\text { ADHD, FD, Downslanted palpebral } \\
\text { fissure, Tall stature, Arachnodactyly, } \\
\text { ID, Polythelia }\end{array}$ & Normal & $\begin{array}{l}15 q 13.3 \\
\text { Pathogenic }\end{array}$ & $\begin{array}{l}0.49 \mathrm{MB} \\
\text { del }\end{array}$ & $\begin{array}{l}\text { (32018731-32515681)x1 } \\
\text { unknown }\end{array}$ & CHRNA7, OTUD7A \\
\hline 15 & $\mathrm{~F} / 2$ & $\begin{array}{l}\text { GDD, Hiperlaxity, Pes planovalgus, } \\
\text { GR, FD }\end{array}$ & \begin{tabular}{|l|} 
Thin CC, dilated \\
lateral ventricles, \\
Arachnoid cyst on \\
posterior fossa, cavum \\
septum pellucidum et \\
verge
\end{tabular} & $\begin{array}{l}\text { 9p24.3p13.1 } \\
\text { Pathogenic }\end{array}$ & 40MB dup & $\begin{array}{l}(46587-40294324) x 3 \\
\text { Unbalanced segregation } \\
\text { of a balanced } \\
\text { translocation(maternal) }\end{array}$ & $\begin{array}{l}\text { ACER2, ACO1, ADAMTSL1, AK3, } \\
\text { ALDH1B1, APTX, AQP3, AQP7, B4GALT1, } \\
\text { BAG1, BNC2, C9orf72, CA9, CBWD1, CCIN, } \\
\text { CCL19, CCL21, CCL27, CD274, CD72, } \\
\text { CDC37L1, CDKN2A, CDKN2B, CER1, } \\
\text { CHMP5, CLTA, CNTFR, CNTLN, CNTNAP3, } \\
\text { CREB3, DCTN3, DDX58, DMRT1, DMRT2, } \\
\text { DMRT3, DMRTA1, DNAI1, DNAJA1, } \\
\text { DNAJB5, DOCK8, ELAVL2, ENHO, EQTN, } \\
\text { ERMP1, EXOSC3,FAM154A, FANCG, } \\
\text { FBXO10, FOCAD, FOXD4, FREM1, } \\
\text { FRMPD1, GALT, GBA2, GLDC, GLIPR2, } \\
\text { GLIS3, GNE, GRHPR, HAUS6, HINT2, } \\
\text { IFNA1, IFNA10, IFNA13, IFNA14, IFNA16, } \\
\text { IFNA17, IFNA2, IFNA21, IFNA4, IFNA5, }\end{array}$ \\
\hline
\end{tabular}




\begin{tabular}{|c|c|c|c|c|c|c|c|}
\hline & & & & & & & $\begin{array}{l}\text { IFNA6, IFNA7, IFNA8, IFNB1, IFNE, IFNK, } \\
\text { IFNW1, IFT74, IGFBPL1, IL11RA, IL33, } \\
\text { INSL4, INSL6, JAK2, KANK1, KCNV2, } \\
\text { KDM4C, KIAAO020, KIAA1161, KIAA1432, } \\
\text { KIF24, KLHL9, LINCO0961, LINGO2, } \\
\text { LURAP1L, MELK, MLANA, MLLT3, } \\
\text { MOB3B, MPDZ, MSMP, MTAP, NDUFB6, } \\
\text { NFIB, NFX1, NOL6, NPR2, NUDT2, PAX5, } \\
\text { PDCD1LG2, PIGO, PLAA, PLGRKT, PLIN2, } \\
\text { PPAPDC2, PRSS3, PSIP1, PTPLAD2, } \\
\text { PTPRD, RCL1, RECK, RFX3, RGP1, RLN1, } \\
\text { RLN2, RNF38, RPS6, RRAGA, RUSC2, } \\
\text { SH3GL2, SHB, SIGMAR1, SIT1, SLC1A1, } \\
\text { SLC24A2, SMARCA2, SMU1, SNAPC3, } \\
\text { SPAG8, SPINK4, STOML2, TAF1L, TEK, } \\
\text { TESK1, TLN1, TMEM261, TMEM8B, } \\
\text { TOMM5, TOPORS, TPD52L3, TPM2, } \\
\text { TTC39B, TUSC1, TYRP1, UBAP1, UBE2R2, } \\
\text { UHRF2, UNC13B, VCP, VLDLR, ZBTB5, } \\
\text { ZDHHC21 }\end{array}$ \\
\hline 16 & $\mathrm{M} / 7$ & $\begin{array}{l}\text { DiGeorge syndrome } \\
\text { SD } \\
\text { GDD, ID, FD, Prominent ears, Sparse } \\
\text { eyebrows, } \\
\text { Widely space nipples, } \\
\text { Left renal agenesis, } \\
\text { Recurrence infection, } \\
\text { Cardiac abnormality }\end{array}$ & Normal & $\begin{array}{l}\text { 22q11.21 } \\
\text { Pathogenic }\end{array}$ & $\begin{array}{l}2.56 \mathrm{MB} \\
\mathrm{del}\end{array}$ & $\begin{array}{l}(18901004-21462353) x 1 \\
\text { Un known }\end{array}$ & $\begin{array}{l}\text { AIFM3, ARVCF, CDC45, CLDN5, CLTCL1, } \\
\text { COMT, CRKL, DGCR14, DGCR2, DGCR6, } \\
\text { DGCR6L, DGCR8, GGTLC3, GNB1L, } \\
\text { GP1BB, GSC2, HIRA, KLHL22, LZTR1, } \\
\text { MED15, MRPL40, P2RX6, PI4KA, PRODH, } \\
\text { RANBP1, RIMBP3, RTN4R, SCARF2, SEPT5, } \\
\text { SERPIND1, SLC25A1, SLC7A4, SNAP29, } \\
\text { TANGO2, TBX1, THAP7, TRMT2A, TSSK2, } \\
\text { TXNRD2, UFD1L, ZDHHC8, ZNF74 } \\
\end{array}$ \\
\hline 17 & $\mathrm{~F} / 2.5$ & $\begin{array}{l}\text { FD, Low-set ears, } \\
\text { High palate, Sleep problem, GDD, } \\
\text { SD, Hypotonia, Atrial septal defect, } \\
\text { GR }\end{array}$ & $\begin{array}{l}\text { Dilated frontal Horne } \\
\text { of the lateral ventricle }\end{array}$ & $\begin{array}{l}\text { 6q15q16.3 } \\
\text { Pathogenic }\end{array}$ & $\begin{array}{l}11.73 \mathrm{KBd} \\
\mathrm{el}\end{array}$ & $(89,181,413-100,914,602) \times 1$ & $\begin{array}{l}\text { PNRC1, PROL2, PM2OD2, ACY1L2, } \\
\text { GABRR1, GABRR2, UBE2J1, UBC6E, } \\
\text { PNRC1, PROL2, SIM1, GRIK2, } \\
\text { MCHR2, ASCC3, EPHA7 }\end{array}$ \\
\hline 18 & $\mathrm{~F} / 2$ & $\begin{array}{l}\text { FD (caput quadratum, trigonocephaly, } \\
\text { downslanted palpebral fissure, low } \\
\text { posterior hairline, high nasal root), } \\
\text { GR, SS, GDD, Febrile status, } \\
\text { epilepticus (generalized motor } \\
\text { seizure) }\end{array}$ & $\begin{array}{l}\text { Delayed myelination } \\
\text { (level of centrum } \\
\text { semiovale, especially } \\
\text { frontal and parietal } \\
\text { deep white matter) }\end{array}$ & $\begin{array}{l}17 \mathrm{p} 13.3 \\
\text { UCS;LP } \\
\\
17 \mathrm{q} 12 \\
\mathrm{UCS} ; \mathrm{LP}\end{array}$ & $\begin{array}{l}0.8 \mathrm{MB} \\
\text { del, } \\
\text { 0.9MB } \\
\text { dup }\end{array}$ & $\begin{array}{l}(1251996-2084712) \times 1 \\
(31993787-32911168) \times 3 \\
\text { unknown }\end{array}$ & $\begin{array}{l}\text { 17p13.3: CRKDPH1, HIC1, INPP5K, } \\
\text { MYO1C, OVCA2, PITPNA, PRPF8, RILP, } \\
\text { RPA1, RTN4RL1, SCARF1, SERPINF1, } \\
\text { SERPINF2, SLC43A2, SMG6, WDR81, } \\
\text { TWHAE / } \\
\text { 17q12: ASIC2, CCL1, CCL11, CCL13, CCL2, } \\
\text { CCL7, CCL8, TMEM132E }\end{array}$ \\
\hline 19 & $\mathrm{M} / 3$ & $\begin{array}{l}\text { SD, GDD, FD (hypotelorism, plump } \\
\text { lip, bitemporal narrowing, high and } \\
\text { narrow palate), waddle walk, asthenia }\end{array}$ & Normal & $\begin{array}{l}\text { 10q11.22 } \\
\text { UCS;NS } \\
\text { 13q34 } \\
\text { UCS;NS }\end{array}$ & $\begin{array}{l}0.7 \mathrm{MB} \\
0.3 \mathrm{MB} \\
\text { dup }\end{array}$ & $\begin{array}{l}(46972140-47701570) \times 3 \\
(113922447-114288971) \times 3 \\
\text { unknown }\end{array}$ & $\begin{array}{l}\text { 10q11.22: GPRIN2,NPY4R } \\
\text { 13q34:ADPRHL1,LAMP1,TFDP1,TMCO3 }\end{array}$ \\
\hline
\end{tabular}




\begin{tabular}{|c|c|c|c|c|c|c|c|}
\hline 20 & $\mathrm{M} / 4$ & $\begin{array}{l}\text { FD, High palate, Low-set ears, } \\
\text { Frontal bossing, Arachnodactyly, } \\
\text { Undescended testicle, GDD, SD }\end{array}$ & $\begin{array}{l}\text { Dilated lateral and } \\
\text { third ventricle, } \\
\text { Increased } \\
\text { subarachnoid space, } \\
\text { Mega cisterna magna, } \\
\text { Increased prepontine } \\
\text { and suprasellar cistern } \\
\text { space }\end{array}$ & $\mid \begin{array}{l}\text { 9p24.3p13.1 } \\
\text { Pathogenic }\end{array}$ & $\begin{array}{l}38.5 \mathrm{MB} \\
\text { dup }\end{array}$ & $\begin{array}{l}(204,198-387,414,37) \times 4 \\
\text { Unbalanced segregation } \\
\text { of a balanced } \\
\text { translocation }\end{array}$ & $\begin{array}{l}\text { ACER2, ACO1, ADAMTSL1, AK3, } \\
\text { ALDH1B1, APTX, AQP3, AQP7, B4GALT1, } \\
\text { BAG1, BNC2, C9orf72, CA9, CBWD1, CCIN, } \\
\text { CCL19, CCL21, CCL27, CD274, CD72, } \\
\text { CDC37L1, CDKN2A, CDKN2B, CER1, } \\
\text { CHMP5, CLTA, CNTFR, CNTLN, CNTNAP3, } \\
\text { CREB3, DCTN3, DDX58, DMRT1, DMRT2, } \\
\text { DMRT3, DMRTA1, DNAI1, DNAJA1, } \\
\text { DNAJB5, DOCK8, ELAVL2, ENHO, EQTN, } \\
\text { ERMP1, EXOSC3,FAM154A, FANCG, } \\
\text { FBXO10, FOCAD, FOXD4, FREM1, } \\
\text { FRMPD1, GALT, GBA2, GLDC, GLIPR2, } \\
\text { GLIS3, GNE, GRHPR, HAUS6, HINT2, } \\
\text { IFNA1, IFNA10, IFNA13, IFNA14, IFNA16, } \\
\text { IFNA17, IFNA2, IFNA21, IFNA4,IFNA5, } \\
\text { IFNA6, IFNA7, IFNA8, IFNB1, IFNE, IFNK, } \\
\text { IFNW1, IFT74, IGFBPL1, IL11RA, IL33, } \\
\text { INSL4, INSL6, JAK2, KANK1, KCNV2, } \\
\text { KDM4C, KIAAO020, KIAA1161, KIAA1432, } \\
\text { KIF24, KLHL9, LINCOO961, LINGO2, } \\
\text { LURAP1L, MELK, MLANA, MLLT3, } \\
\text { MOB3B, MPDZ, MSMP, MTAP, NDUFB6, } \\
\text { NFIB, NFX1, NOL6, NPR2, NUDT2, PAX5, } \\
\text { PDCD1LG2, PIGO, PLAA, PLGRKT, PLIN2, } \\
\text { PPAPDC2, PRSS3, PSIP1, PTPLAD2, } \\
\text { PTPRD, RCL1, RECK, RFX3, RGP1, RLN1, } \\
\text { RLN2, RNF38, RPS6, RRAGA, RUSC2, } \\
\text { SH3GL2, SHB, SIGMAR1, SIT1, SLC1A1, } \\
\text { SLC24A2, SMARCA2, SMU1, SNAPC3, } \\
\text { SPAG8, SPINK4, STOML2, TAF1L, TEK, } \\
\text { TESK1, TLN1, TMEM261, TMEM8B, } \\
\text { TOMM5, TOPORS, TPD52L3, TPM2, } \\
\text { TTC39B, TUSC1, TYRP1, UBAP1, UBE2R2, } \\
\text { UHRF2, UNC13B, VCP, VLDLR, ZBTB5, } \\
\text { ZDHHC21 }\end{array}$ \\
\hline 21 & $\mathrm{M} / 4$ & $\begin{array}{l}\text { Epilepsy (generalized motor seizures), } \\
\text { GDD, FD, Camptodactyly, } \\
\text { strabismus, SD }\end{array}$ & Normal & $\begin{array}{l}\text { 7q31.1q31.31 } \\
\text { Pathogenic }\end{array}$ & $10 \mathrm{MB}$ dup & $\begin{array}{l}(107593989-118062404) x 1 \\
\text { unknown }\end{array}$ & $\begin{array}{l}\text { PPP1R3A,MET,FOXP2,CAV1,ANKRD7,ASZ } \\
\text { 1,C7orf60,CAPZA2,CAV1,CAV2,CFTR,CTTN } \\
\text { BP2,DNAJB9,DOCK4 }\end{array}$ \\
\hline 22 & $\mathrm{M} / 6$ & $\begin{array}{l}\text { SD, Autism, GDD, ID, Prominent } \\
\text { beak nose }\end{array}$ & Normal & $\begin{array}{l}7 q 35 \\
\text { UCS;LP } \\
\text { Xq27.1q27.2 } \\
\text { Pathogenic }\end{array}$ & $\begin{array}{l}0.13 \mathrm{MB} \\
\text { del, } \\
1.2 \mathrm{MB} \\
\text { dup }\end{array}$ & $\begin{array}{l}(145878672-146017091) \times 1 \\
(139584651-140801014) 2 \times 3 \\
\text { unknown }\end{array}$ & $\begin{array}{l}\text { 7q35: } C N T N A P 2 \\
\text { Xq27.1q27.2: SOX3, CDR1, SPANXB1, } \\
\text { LDOC1, SAPNXA1, SAPNXA2, SPANXD, } \\
\text { SPANXC }\end{array}$ \\
\hline
\end{tabular}




\begin{tabular}{|c|c|c|c|c|c|c|c|}
\hline 23 & $\mathrm{~F} / 4$ & $\begin{array}{l}\text { GDD, SD, FD (happy face, low-set } \\
\text { ears) }\end{array}$ & \begin{tabular}{|l|} 
Corpus callosum \\
hypoplasia (body) and \\
agenesis (splenium)
\end{tabular} & $\begin{array}{l}\mathrm{Xq} 25 \\
\mathrm{UCS} ; \mathrm{NS}\end{array}$ & $0.4 \mathrm{MB}$ del & $\begin{array}{l}(122869800-123283576) \times 4 \\
\text { unknown }\end{array}$ & $X I A P, S T A G 2$ \\
\hline 24 & $\mathrm{M} / 3.5$ & $\begin{array}{l}\text { SD, FD (hypotelorism, macrocephaly, } \\
\text { high palate, low set ear, flat occiput, } \\
\text { left epicanthus, synophrys, local } \\
\text { alopecia on temporal area), GDD, } \\
\text { Autism }\end{array}$ & Normal & $\begin{array}{l}\text { 12q24.13q24.21 } \\
\text { UCS;LP }\end{array}$ & $\begin{array}{l}0.28 \\
\text { MB dup }\end{array}$ & $\begin{array}{l}(114267718-114552522) \times 3 \\
\text { unknown }\end{array}$ & RBM19 \\
\hline 25 & $\mathrm{M} / 7$ & $\begin{array}{l}\text { SD, ID, FD, Macrocephaly, Ataxia } \\
\text { ATX gene: normal }\end{array}$ & $\begin{array}{l}\text { Frontotemporal } \\
\text { atrophy, } \\
\text { Cavum septum } \\
\text { pellucidum et vergae } \\
\end{array}$ & $\begin{array}{l}\text { 1q21.1 } \\
\text { Pathogenic }\end{array}$ & $\begin{array}{l}0.36 \mathrm{MB} \\
\mathrm{del}\end{array}$ & $\begin{array}{l}(14538817-145755813) x 1 \\
\text { unknown }\end{array}$ & $\begin{array}{l}\text { CD160,HFE2,ITGA10,PDZK1,PEX11B,PIAS } \\
\text { 3,POLR3C,POLR3GL,RBM8A,TXNIP }\end{array}$ \\
\hline 26 & $\mathrm{~F} / 2$ & $\begin{array}{l}\text { GDD, SD, GR, } \\
\text { Microcephaly, FD, Low-set ears } \\
\text { Abnormal earlobe shape }\end{array}$ & $\begin{array}{l}\text { Cerebral atrophy } \\
\text { Myelination delay }\end{array}$ & $\begin{array}{l}\text { 1q21.1q21.2 } \\
\text { Pathogenic }\end{array}$ & $3.5 \mathrm{MB}$ del & $\begin{array}{l}(145415190-148936712) \times 4 \\
\text { unknown }\end{array}$ & $\begin{array}{l}\text { NBPF20,NBPF10,TXNIP,RBM8A,GNRHR2, } \\
\text { PEX11B,ITGA10,PIAS3,CD160,PDZK1,GPR } \\
89, N B P F 11, N B P F 12, P R K A B 2, F M O 5, C H D 1 \\
\text { L,BCL9,ACP6,GJA5,GJA8,GPR89B,NBF8,P } \\
\text { PAL4A,NBPF14,NBPF9,NBPF15 }\end{array}$ \\
\hline 27 & $\mathrm{~F} / 2.5$ & $\begin{array}{l}\text { Wolf Hirchorn syndrome, } \\
\text { Epilepsy (focal motor seizures), GR } \\
\text { Microcephaly } \\
\text { SD, Cleft palate } \\
\text { FD, GDD }\end{array}$ & $\begin{array}{l}\text { Thin } \mathrm{CC}, \\
\text { Myelination delay }\end{array}$ & $\begin{array}{l}\text { 4p16.3p16.1 } \\
\text { Pathogenic }\end{array}$ & $10 \mathrm{MB}$ del & $\begin{array}{l}(72447-103,372,96) \times 3 \\
\text { unknown }\end{array}$ & $\begin{array}{l}\text { ZNF141, PDE6B, ATP5I, MYL5, CPLX1, } \\
\text { GAK, TMEM175, DGKQ, IDUA, FGFRL1, } \\
\text { RNF212, SPON2, CTBP1, MAEA, UVSSA, } \\
\text { CRIPAK, SLBP, TMEM129, TACC3, FGFR3, } \\
\text { LETM1, WHSC1, C4Orf48, NAT8L, POLN, } \\
\text { HAUS3, ZFYVE28, RNF4, TNIP2, SH3BP2, } \\
\text { ADD1, NOP14, GRK4, HTT, RGS12, } \\
\text { HGFAC, DOK7, LRPAP1, ADRA2C, OTOP1, } \\
\text { ZBTB49, MSX1, CYTL1, EVC2, EVC, } \\
\text { CRMP1, JAKMIP1, WFS1, PPP2R2C, } \\
\text { S1OOP, BLOC1S4, TBC1D14, TADA2B, } \\
\text { GRPEL1, SORCS2, AFAP1, ABLIM2, } \\
\text { MIR95, HTRA3, ACOX3, GPR78, CPZ, } \\
\text { HMX1, USP17L9P, DRD5, SLC2A9, WDR1 }\end{array}$ \\
\hline 28 & $\mathrm{~F} / 9.5$ & $\begin{array}{l}\text { 1p36 syndrome, Triple X syndrome, } \\
\text { Moya moya syndrome, ID, Drug } \\
\text { resistant epilepsy (focal motor, } \\
\text { seconder generalized motor and non- } \\
\text { motor seizures), GDD, SD, FD }\end{array}$ & $\begin{array}{l}\text { Thin CC (Corpus and } \\
\text { splenium, Ivy sign of } \\
\text { moya moya. }\end{array}$ & $\begin{array}{l}\text { 1p36.32p36.32 } \\
\text { Pathogenic } \\
\text { Xp22.33q28 } \\
\text { Pathogenic }\end{array}$ & $1.8 \mathrm{MB}$ del & $\begin{array}{l}(2951244-4763189) \times 1 \\
(93118-155235833) \times 3 \\
\text { De novo }\end{array}$ & $\begin{array}{l}\text { AJAP1,CEP104,DFFB,MEGF6,PRDM16,SM } \\
\text { IM1,TP73,TPRG1L,WRAP73 }\end{array}$ \\
\hline 29 & $\mathrm{~F} / 9.5$ & $\begin{array}{l}\text { Epilepsy (generalized motor seizure, } \\
\text { drug-resistant epilepsy), FD (coarse } \\
\text { face, plump lip, short filtrum, } \\
\text { prognathia), GDD, SS }\end{array}$ & $\begin{array}{l}\text { Cerebellar tonsils } 5 \\
\mathrm{~mm} \text { below the level of } \\
\text { the foramen magnum. }\end{array}$ & $\begin{array}{l}2 \mathrm{q} 37.3 \\
\text { UCS;NS }\end{array}$ & $0.5 \mathrm{MB}$ del & $\begin{array}{l}\text { 242517966-243029573)x1 } \\
\text { unknown }\end{array}$ & $\begin{array}{l}\text { THAP4,ATG4B,DTYMK,ING5,D2HGDH,GA } \\
\text { L3ST2,NEU4,PDCD1 }\end{array}$ \\
\hline
\end{tabular}




\begin{tabular}{|c|c|c|c|c|c|c|c|}
\hline 30 & $\mathrm{M} / 12$ & $\begin{array}{l}\text { FD, High and narrow palate, Flat } \\
\text { occiput, Deep-set eyes, Hypotelorism, } \\
\text { Microcephaly, Fusiform finger shape, } \\
\text { Micropenis } \\
\text { GDD, ID }\end{array}$ & Normal & $\begin{array}{l}\text { Xp21.31q22.2 } \\
\text { Pathogenic }\end{array}$ & $\begin{array}{l}12.7 \mathrm{MB} \\
\text { dup }\end{array}$ & $\begin{array}{l}(90301668-103038108) x 4 \\
\text { unknown }\end{array}$ & $\begin{array}{l}\text { PABPC5, PCDH11X, NAP1L3, DIAPH2, } \\
\text { RPA4, PCDH19, TNMD, TSPAN6, SRPX2, } \\
\text { SYTL4, NOX1, XKRX, DRP2, TAF7L, } \\
\text { TIMM8A, BTK, RPL36A, GLA, ARMCX1, } \\
\text { ARMCX2, ARMCX3, NXF5, BEX5, NXF2, } \\
\text { TMSB15A, NXF4, GPRASP1, BHLHB9, } \\
\text { RAB4OAL, BEX1, NXF3, BEX4, BEX2, } \\
\text { TCEAL7, BEX3, TCEAL1, PLP1 }\end{array}$ \\
\hline 31 & $\mathrm{M} / 8$ & $\begin{array}{l}\text { SD, FD (brachydactyly, teeth } \\
\text { hypoplasia, short fingers), ADHD, } \\
\text { SS, ID }\end{array}$ & Normal & $\begin{array}{l}\text { p } 15.33 \\
\text { UCS;NS } \\
\text { 8q22.1 } \\
\text { UCS;NS } \\
\end{array}$ & $\begin{array}{l}0.29 \mathrm{MB} \\
\text { dup } \\
1.1 \mathrm{MB} \\
\text { dup }\end{array}$ & $\begin{array}{l}(956671-1255361) \times 3 \\
(9716932-98301557) \times 3 \\
\text { unknown }\end{array}$ & $\begin{array}{l}\text { 5p15.33: NKD2, SLC12A7, SLC6A19, TERT / } \\
\text { 8q22.1: GDF6, MTERFD1, PTDSS1, SDC2, } \\
\text { TSPYL5, UQCRB }\end{array}$ \\
\hline 32 & $\mathrm{M} / 14$ & $\begin{array}{l}\text { ID, Drug-resistant epilepsy (focal } \\
\text { motor seizures) } \\
\text { SD }\end{array}$ & Normal & $\begin{array}{l}\text { 17q12q21.2 } \\
\text { UCS;LP }\end{array}$ & $\begin{array}{l}2.7 \mathrm{MB} \\
\operatorname{dup}\end{array}$ & $\begin{array}{l}(385,802,44-386,06,106) \times 3 \\
\text { unknown }\end{array}$ & $\begin{array}{l}\text { DDX52, HNF1B, TBC1D3C, TBC1D3H, } \\
\text { TBC1D3, TBC1D3G, TBC1D3E, MRPL45, } \\
\text { GPR179, ARHGAP23, MLLT6, CISD3, } \\
\text { PSMB3, RPL23, LASP1, FBXO4, PLXDC1, } \\
\text { CACNB1, RPL19, FBXL20, MED1, CDK12, } \\
\text { NEUROD2, STARD3, TCAP, PNMT, PGAP3, } \\
\text { ERBB2, GRB7, IKZF3, ZPBP2, GSDMB, } \\
\text { ORMDL3, GSDMA, CSF3, MED24, THRA, } \\
\text { NR1D1, MSL1, SDO6, RARA, GJD3, TOP2A, } \\
\text { IGFBP4, }\end{array}$ \\
\hline 33 & $\mathrm{~F} / 12$ & $\begin{array}{l}\text { ID, SD, FD (big prominent ears, flat } \\
\text { nasal root), GR, Epilepsy (motor } \\
\text { seizure) }\end{array}$ & Normal & $\begin{array}{l}\text { 10q21.1q21.2 } \\
\text { Pathogenic } \\
\text { 10q21.2q22.1 } \\
\text { UCS;LP }\end{array}$ & $\begin{array}{l}\begin{array}{l}3.7 \mathrm{MB} \\
\text { dup }\end{array} \\
\text { 7.6MB } \\
\text { dup }\end{array}$ & $\begin{array}{l}(59897533-63600048) \times 3 \\
(63685902-71376096) \times 3\end{array}$ & $\begin{array}{l}\text { 10q21.1q21.2:ANK3,BICC1,CCDC6,CDK1, } \\
\text { CISD1, IPMK, LINCOO948, RHOBTB1, } \\
\text { SLC16A9,TFAM, TEMEM2 6, UBE2D1 } \\
\\
\text { 10q21.2q22.1: ADO, ARID5B, ATOH7, } \\
\text { CCAR1, CTNNA3, DDX21, DDX5O DNA2 } \\
\text { DNAJC12, EGR2, HERC4, HK1, HKDC1, } \\
\text { HNRNPH3, JMJD1C, KIAA1279, LRRTM3, } \\
\text { MYPNA, NEUROG3, NRBF2, PBLD, REEP3, } \\
\text { RTKN2, SIRT1, SLC25A16, SRGN, STOX1 } \\
\text { SUPV3L1, TACR2, TET1, TSPAN15, } \\
\text { VPS26A, ZNF365 }\end{array}$ \\
\hline & & & & & & unknown & \\
\hline 34 & $\mathrm{M} / 2.5$ & $\begin{array}{l}\text { Epilepsy (generalized motor seizures), } \\
\text { FD, Synophrys, } \\
\text { Micrognathia, Prominent, beak shape } \\
\text { nose, GDD } \\
\text { NIPBL gene: normal }\end{array}$ & Normal & $\begin{array}{l}\text { 15q13.3 } \\
\text { UCS;NS }\end{array}$ & $\begin{array}{l}\text { 0.49MB } \\
\text { dup }\end{array}$ & $\begin{array}{l}(32020066-32515681) \times 3 \\
\text { unknown }\end{array}$ & CHRNA7, OTUD7A \\
\hline
\end{tabular}

